\title{
EVALUASI KEBERLANJUTAN PENERAPAN LANGKAH-LANGKAH BIOSEKURITI PADA PETERNAKAN AYAM BROILER DI DESA SELANBAWAK, KECAMATAN MARGA, KABUPATEN TABANAN
}

\author{
SARINI 1), N. P., N. N. SURYANI ${ }^{2)}$, NI PUTU MARIANI ${ }^{2)}$, A.A. OKA ${ }^{3)}$, M. DEWANTARI ${ }^{4)}$ \\ 1) Laboratorium Pemuliaan Ternak dan Biomolekular. ${ }^{2)}$ Laboratorium Nutrisi dan Makanan Ternak. \\ ${ }^{3)}$ Laboratorium Ternak Potong. ${ }^{4}$ Laboratorium Statistik, Fakultas Peternakan Universitas Udayana \\ e-mail: sarini@unud.ac.id
}

\begin{abstract}
ABSTRAK
Merebaknya flu burung (AI) ke Indonesia pada tahun 2003 memberikan dampak yang sangat merugikan bagi industri perunggasan. Upaya pemerintah untuk menjadikan biosekuriti sebagai garda terdepan untuk mencegah penyakit menular pada peternakan mendapat sambutan dari semua pemangku kepentingan industri perunggasan. Meskipun wabah flu burung (AI) di Indonesia saat ini sudah mereda, tetapi kontrol terhadap HPAI (Highly Pathogenic Avian Influenza) masih merupakan prioritas utama dalam pengendalian penyakit pada peternakan ayam. Tujuan penelitian ini adalah untuk mengkaji keberlanjutan pelaksanaan langkah-langkah biosekuriti pada peternakan ayam broiler dan kebutuhan pendampingan (mentoring) untuk pencegahan berjangkitnya kembali wabah flu burung. Penelitian dilaksanakan dengan metode survei terhadap responden peternak ayam broiler di Desa Selanbawak, Kecamatan Marga, Kabupaten Tabanan. Sampel pada penelitian ini adalah semua peternak yang terlibat dalam Proyek ACIAR AH/169/2006 yang ada di desa tersebut yang sudah mendapatkan pelatihan dan pembinaan penerapan langkah langkah biosekuriti. Data yang diperoleh akan dianalisis dengan deskriptif kualitatif dengan pendekatan analisis scoring berdasarkan kriteria langkah-langkah biosekuriti. Hasil penelitian menunjukkan bahwa langkah-langkah penerapan biosekuriti pada peternakan ayam di atas sudah berubah, meskipun bangunan fisik dari beberapa langkah penerapan seperti adanya pagar, pintu pagar dan footbath masih ada tetapi tidak dapat berfungsi sebagai mana mestinya.
\end{abstract}

Kata kunci: biosekuriti, ayam broiler, flu burung

\section{SUSTAINABILITY EVALUATION OF BIOSECURITY IMPLEMENTATION ON THE BROILER FARMS IN SELANBAWAK VILLAGE, MARGA DISTRICT, TABANAN REGENCY}

\begin{abstract}
The entry of Avian Influenza (AI) to Indonesia in 2003 gave a tremendously negative impact on poultry businesses. Biosecurity is one of the government efforts to protect the spread of infectious diseases to the farms. It gets a good response from all the stakeholders in the poultry industry. Although there are no Avian Influenza outbreaks anymore, control to the Highly Pathogenic Avian Influenza (HPAI) is still becoming a main priority in controlling diseases in the poultry farms. This research was conducted to evaluate the sustainability of biosecurity implementation in the broiler farms and mentored requirement to prevent AI outbreaks from occurring again. A survey was used to gain information on broiler famers at Selanbawak Village. The samples in this study were all the farmers who were involved in the ACIAR project AH/2006/169. They had been trained and supervised to implement biosecurity measures in their farms. The data obtained were descriptive-qualitatively analyzed using percentage approach based on the biosecurity implementation criteria. It was found that the biosecurity measures implemented by those farmers had not been maintained. Most of the farms were untidy; and rubbishes and bushes were scattered around the farms. The footbath was not properly used as sanitary equipment, and even some were buried with cement.
\end{abstract}

Key words: biosecurity, broiler chicken, Avian Influenzia 


\section{PENDAHULUAN}

Produksi peternakan ayam broiler dewasa ini berkembang sangat pesat seiring dengan semakin meningkatnya permintaan pasar terhadap ayam broiler. Ayam broiler merupakan salah satu sumber protein hewani yang banyak dikonsumsi oleh masyarakat karena harganya yang terjangkau. Pemerintah Indonesia telah menerapkan beberapa program dan kebijaksanaan untuk mendorong peningkatan produksi ayam untuk memenuhi kebutuhan yang disebabkan oleh peningkatan populasi penduduk. Tetapi peningkatan produksi tersebut pernah mengalami hal yang sangat buruk saat meluasnya wabah flu burung atau avian influenza (AI) di Indonesia, yang mengguncang industri perunggasan nasional dan menimbulkan kerugian yang tidak sedikit (Sulaiman, 2007; FAO,2012). Kerugian secara ekonomis yang disebabkan oleh Highly Pathogenic Avian Influenza (HPAI) ini diperkirakan mencapai 1 juta dolar Amerika (ABCRC, 2007).

Penyakit flu burung yang disebabkan oleh penyebaran virus HPAI telah menimbulkan korban yang cukup tinggi di Asia Tenggara dan pada belahan wilayah Asia Timur lainnya. Lebih dari 200 orang korban meninggal dunia dan lebih dari 200 juta ekor unggas telah dipotong atau dimusnahkan. Sejak pertama kali diidentifikasi pada tahun 2003, penyakit tersebut telah menjadi endemi pada 31 provinsi dari 33 provinsi di Indonesia.

Di antara berbagai penyakit unggas lainnya seperti tetelo, gumboro, dan sebagainya, flu burung dianggap sebagai penyakit yang paling signifikan menurunkan kinerja ekonomi, khususnya bagi Sektor Perunggasan Non-Industri Komersial atau Non-Industrial Commercial Poultry Sector (NICPS) serta sektor unggas perdesaan (tradisional). NICPS didefinisikan sebagai usaha ternak unggas komersial yang tidak dimiliki dan tidak dikelola oleh tujuh perusahaan besar multinasional yang beroperasi di Indonesia. Sektor ini terdiri dari usaha ternak unggas pedaging dan petelur mulai dari produsen skala kecil semi-komersial mandiri (50o ekor) dengan tingkat biosekuriti rendah atau minim hingga produsen skala besar yang terintegrasi (100.000 ekor) dengan penerapan sistem biosekuriti yang lebih baik.

Penerapan biosekuriti berdasarkan prinsip agar penyakit tidak masuk ke peternakan dan agar peternakan tidak membawa penyakit ke luar dari peternakan. Program biosekuriti yang efektif akan menjaga agar peternakan bebas dari penyakit, atau apabila ada agen penyakit, program biosekuriti akan mengeliminasi agen penyakit tersebut atau menurunkan jumlahnya sampai ke level yang tidak berbahaya (Butcher, 2013). Biosekuriti yang baik, mampu menghasilkan angka kematian yang lebih sedikit pada unggas serta penghematan yang cukup besar dalam biaya produksi, sehingga memberikan pendapatan yang lebih tinggi bagi peternak. Biosekuriti yang baik juga mampu mengelola ternak secara semestinya dan mengurangi kontaminasi.

Dalam upaya penanggulangan HPAI, pemerintah Australia melalui ACIAR (AH/2006/169) bekerja sama dengan pemerintah Indonesia di tiga provinsi (Jawa Barat, Bali, dan Sulawesi Selatan) melaksanakan proyek penerapan biosekuriti pada peternakan ayam di sektor tiga (NICPS). Di Bali sendiri ada sekitar 160 peternak ayam broiler yang merupakan mitra dari 3 perusahaan besar. Sebagian dari peternak tersebut diberikan pelatihan biosekuriti dan sekitar 60 peternak ayam broiler dibina dan dibantu dalam menerapkan langkahlangkah biosekuriti yang tepat guna dan disesuaikan dengan kondisi peternakan yang bersangkutan. Diantara peternak yang dilatih dan dibina tersebut yang berlokasi di Bali adalah peternak di Desa Selanbawak, Kecamatan Marga, kabupaten Tabanan.

Mengingat banyaknya jenis penyakit hewan menular pada unggas yang disebabkan oleh virus telah dilaporkan keberadaannya di Indonesia, meskipun penyakit yang dianggap utama saat ini pada ayam yang disebabkan oleh virus, yaitu Avian Influenza (AI) atau Flu burung, penyakit seperti Newcastle Disease (ND) atau Tetelo, Infeksius Bronchitis (IB), Infectious Laryngotracheitis (ILT), penyakit Marek, dan Infectious Bursal Disease (IBD) atau Gumboro, semuanya itu juga bisa dicegah dengan pelaksanaan biosekuriti.

Meskipun wabah flu burung (AI) di Indonesia saat ini sudah mereda, tetapi kontrol terhadap HPAI masih merupakan prioritas utama dalam pengendalian penyakit pada peternakan ayam. Upaya pemerintah untuk menjadikan biosekuriti sebagai garda terdepan untuk mencegah penyakit menular pada peternakan mendapat sambutan dari semua pemangku kepentingan pada industri perunggasan Indonesia. Peternak sendiri bisa mengatur implementasinya disesuaikan dengan kondisi cuaca dan penyakit yang mewabah, artinya kalau kondisi aman tidak ada wabah cuaca bagus penerapan biosekuriti bisa dilonggarkan demikian juga sebaliknya bila sedang terjangkit wabah biosekuriti harus diperketat.

Proyek ACIAR ini berlangsung selama 4 tahun (2008 -2012), setelah berakhir diharapkan penerapan langkah-langkah biosekuriti yang sudah diterapkan oleh peternak tersebut dapat dilaksanakan secara terus menerus, bahkan makin banyak peternak yang menerapkan langkah-langkah tersebut. 


\section{MATERI DAN METODE}

\section{Lokasi dan Materi Penelitian}

Lokasi penelitian ini dilaksanakan pada peternakan ayam broiler yang merupakan peternakan mitra di Desa Selanbawak, Kecamatan Marga, Kabupaten Tabanan yang telahd ilatih, dibina dalam menerapkan langkah-langkah biosekuriti dan diaudit oleh auditor biosekuriti serta memperoleh sertifikat dari PBUI (Pusat Biosekuriti Unggas Indonesia) dengan kriteria peternakan biosecure.

\section{Metode Pengumpulan Data}

Metode pengumpulan data yang digunakan dalam penelitian ini meliputi:

1. Survei: metode pengumpulan data dengan menggunakan kuesioner yang telah dipersiapkan terlebih dahulu untuk memperoleh informasi atau data yang dibutuhkan.

2. Wawancara: suatu proses untuk mendapatkan informasi untuk kepentingan penelitian dengan cara dialog dan bertukar ide melalui tanya jawab antara peneliti dengan responden (Esterberg, 2002 dalam Sugiyono, 2008).

Penelitian ini dilaksanakan dengan survei ke peternakan ayam broiler yang berjumlah lebih kurang 20 peternak untuk mengetahui penerapan biosekuriti pada peternakan dengan memberikan pertanyaan yang terstruktur (kuisioner) dan juga melihat langsung kondisi penerapan langkah-langkah biosekuriti yang masih dilaksanakan oleh peternakan ayam broiler tersebut untuk kemudian didokumentasikan.

\section{Analisis Data}

Metode analisis yang digunakan dalam penelitian ini adalah dengan analisis deskriptif kualitatif. Metode analisis deskriptif kualitatif digunakan untuk mendeskripsikan penerapan langkah-langkah biosekuriti pada 3 lokasi dari 9 tempat (Gambar 1) yang bisa dievaluasi yaitu:
1. Biosecurity at farm boundary/Pre entry. Biosekuriti pada pintu masuk peternakan (pagar, pintu pagar)

2. Biosecurity between farm boundary and shed/ Point of entry. Biosekuriti diantara pintu masuk peternakan dan kandang (daerah antara pagar dan kandang)

3. Biosecurity at shed door/Post entry, biosekuriti pada pintu kandang (pintu kandang)

Untuk menjawab tujuan penelitian yaitu dengan menggunakan pendekatan persentase dari penerapan langkah-langkah biosekuriti pada ketiga pintu masuk diatas.

\section{HASIL DAN PEMBAHASAN}

Dari sembilan lokasi yang bisa dievaluasi (Gambar 1) hanya dipilih tiga lokasi mengingat semua peternak yang dievaluasi merupakan peternakan mitra dari perusahaan yang sama. Ini dapat dikatakan kondisi dari input produksi semua peternakan tersebut sama. Semua peternakan juga berada di desa yang sama, sehingga kondisi alam maupun jarak peternakan dengan sumbersumber patogen seperti pasar, jalan raya perumahan tidak ada perbedaan atau bisa dikatakan hampir sama. Jadi lokasi evaluasi yang no. 1 sampai dengan no. 4, 8 dan 9 tidak dilakukan mengingat hal tersebut di atas.

Hasil evaluasi penerapan langkah-langkah biosekuriti pada peternakan ayam broiler di Desa Selanbawak, Kecamatan Marga, Kabupaten Tabanan pada ketiga lokasi dapat dilihat padaTabel 1.

Pada lokasi pre entry, ada enam langkah biosekuriti yang dievaluasi (Tabel 1). Lokasi pre entry ini merupakan pertahanan pertama dari sebuah peternakan terhadap patogen-patogen yang akan memasuki peternakan tersebut. Pada saat pelaksanaan proyek ACIAR (2008 2012) semua peternakan yang terlibat, peternakannya mempunyai pagar karena mereka mendapat bantuan

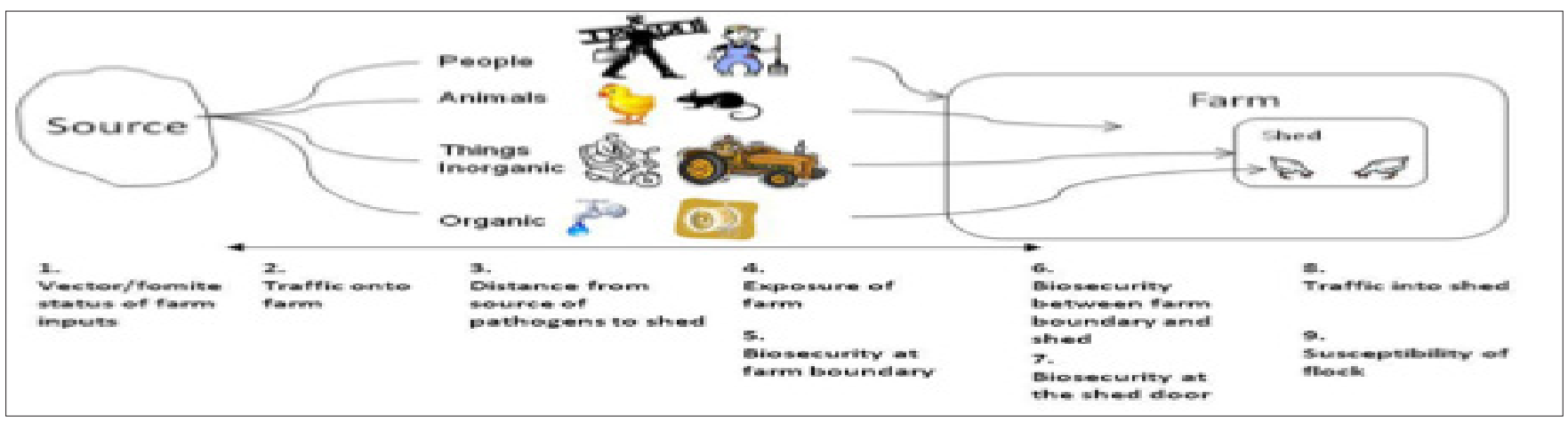

Gambar 1. Sebuah model biosekuriti pada peternakan ayam yang menujukan area dimana penerapan biosekuriti bisa dievaluasi atau dinilai (Patrick and Jubb, 2010) 
Tabel 1. Penerapan langkah-langkah biosekuriti pada pre entry pada peternakan ayam broiler di Desa Selanbawak, Kecamatan Marga, Kabupaten Tabanan

\begin{tabular}{lcc}
\hline No. $\quad$ Langkah-langkah biosekuriti & Project (\%) & Pasca Project (\%) \\
\hline 1. Ada pagar pada peternakan & 100 & 81,25 \\
2. Ada pintu pada pagar & 100 & 81,25 \\
3. Pintu pagar mempunyai gembok & 100 & 68,75 \\
4. Tanda larangan pada pintu pagar & 100 & 75,00 \\
5 Hewan bisa melewati pagar & 0,00 & 93,75 \\
6 Alat semprot kendaraan & 100,00 & 0,00 \\
\hline
\end{tabular}

untuk mendirikan pagar dan pintu dari bahan yang sederhana sampai ada juga dengan bantuan tersebut membuat pagar dengan pintu permanen. Semua peternakan juga memagari peternakannya dengan pagar keliling yang terbuat dari jaring (Gambar 1).

Pertahanan berikutnya dari suatu peternakan adalah pada area point of entry. Langkah-langkah pada area ini merupakan pertahanan yang bertujuan mengurangi patogen yang berhasil melewati area pre entry. Tabel 2 menunjukkan langkah-langkah biosekuriti pada point of entry yang dievaluasi.

Tabel 2. Penerapan langkah-langkah biosekuriti pada point of entry pada peternakan ayam broiler di Desa Selanbawak, Kecamatan Marga, Kabupaten Tabanan

\begin{tabular}{lrr}
\hline No. $\quad$ Langkah-langkah biosekuriti & Project (\%) & $\begin{array}{c}\text { Pasca } \\
\text { Project (\%) }\end{array}$ \\
\hline 1 Ada genangan air di Peternakan & 0,00 & 0,00 \\
2 Ada tempat cuci tangan dan kaki & 100,00 & 100,00 \\
3 Ada ayam kampung di peternakan & 0,00 & 25,00 \\
4 Gudang pakan terpisah dengan kandang & 31,25 & 31,25 \\
5 Hewan bisa memasuki tempat pakan & 0,00 & 27,00 \\
\hline
\end{tabular}

Penerapan langkah-langkah biosekuriti pada area post of entry ditujukan untuk mencegah semaksimal mungkin pathogen-patogen yang berhasil lolos melewati kedua area sebelumnya memasuki kandang yang kemudian menyebabkan ayam sakit. Tabel 3 menunjukkan 7 langkah yang dievaluasi pada area post of entry.

Tabel 3. Langkah-langkah biosekuriti pada post of entry pada peternakan ayam broiler di Desa Selanbawak, Kecamatan Marga, Kabupaten Tabanan

\begin{tabular}{lcc}
\hline No. Langkah-langkah biosekuriti & Project (\%) & $\begin{array}{c}\text { Pasca } \\
\text { Project (\%) }\end{array}$ \\
\hline 1. Kandang mempunyai pintu & 100,00 & 100,00 \\
2. Pintu mempunyai gembok & 100,00 & 25,00 \\
3. Ada tanda larangan pada pintu & 100,00 & 81,25 \\
4. Ada footbath di depan pintu & 100,00 & 93,75 \\
5. Footbath berisi Hasil air & 100,00 & 25,00 \\
6. Footbath berisi desinfektan & 100,00 & 25,00 \\
7. Burung /hewan liar bisa memasuki kandang & 0,00 & 100,00 \\
\hline
\end{tabular}

Setelah empat tahun proyek ACIAR berakhir dapat dilihat bahwa sebagian besar langkah-langkah biosekuriti yang diterapkan oleh peternak sudah berubah. Walaupun wujud dari penerapan langkahlangkah tersebut sebagian besar masih ada tetapi kondisinya sudah rusak. Salah satu contoh yang paling krusial perananya didalam biosekuriti adalah pagar keliling dan pintu pada pagar. Pagar dan pintu sebagian besar masih ada hanya pagar keliling yang terbuat dari jaring sudah rusak sehingga hewan liar seperti ayam kampung bisa dengan leluasa memasuki peternakan (Tabel 1). Kondisi ini tentunya sudah tidak sesuai dengan tujuan dari pelaksanaan langkah-langkah biosekuriti yaitu untuk mencegah pembawa patogen memasuki areal peternakan yang dikahwatirkan akan menularkan bibit penyakit kepada ayam yang dipelihara. Hal ini sejalan dengan pendapat Jeffrey (2007) yang mengatakan bahwa komponen pertama dari penerapan langkah-langkah biosekuriti adalah isolasi.

Demikian juga halnya penerapan langkah biosekuriti pada point of entry (Tabel 2), pada point ini yang paling mencerminkan penerapan biosekuriti adalah kebersihan atau sanitasi dan isolasi tetap berlaku pada semua point. Pada point ini peternak masih tetap menjaga lingkungan peternakannya tetap kering, tidak ada genangan air atau tanah becek terlihat tetapi kebersihan peternakannya kurang mendapat perhatian. Kalau untuk menjaga kebersihan lingkungan dimana-mana peternak memang pelaksaannya sangat rendah, seperti yang diperoleh oleh Saadah et al. (2010) mendapatkan bahwa dari langkah - langkah biosekuriti yang diterapkan peternak ayam broiler dan petelur di Sulawesi selatan hanya 30\% untuk sanitasi. Walaupun mereka menyadari betapa pentingnya sanitasi dalam usaha peternakan mereka tetapi mereka tetap berpendapat bahwa memang peternakan sudah biasa kotor.

Jubb dan Dharma (2008) mengatakan bahwa faktor resiko yang penting bagi peternakan ayam broiler adalah hewan liar seperti ayam kampung, tikus, dan lain-lain. Sehingga penting untuk diketahui oleh peternak bahwa tidak boleh ada hewan liar seperti ayam kampung di peternakan. Evaluasi menunjukkan bahwa sebanyak 25\% dari peternak sekarang memelihara ayam kampung untuk memanfaatkan sisa pakan maupun pakan yang tercecer. Hal ini tentunya bertentangan dengan prinsip biosekuriti yaitu untuk mengurangi kontaminasi ternak yang dipelihara dengan faktor resiko karena peternak dengan sengaja memelihara faktor resiko tersebut di peternakannya. Tidak hanya ayam broiler yang harus dihindari dari hewan liar, pakan ayam juga harus dihindari karena nantinya akan diberikan kepada ayam. Ketika hal tersebut ditanyakan kepada peternak, mereka mengatakan bahwa kondisi sekarang sudah aman tidak ada wabah penyakit sehingga tidak perlu dikahwatirkan. Ini menunjukkan bahwa pengetahuan peternak mengenai fungsi dari pelaksanaan biosekuriti 
tersebut perlu disegarkan lagi. Dari pernyataan peternak tersebut seolah-olah pelaksanaan biosekuriti itu hanya diperlukan bila terjadi wabah, padahal sebenarnya biosekuriti itu merupakan salah satu komponen dari tatalaksana beternak yang baik. Pada saat ada wabah, pelaksanaan biosekuriti harus diperketat sedangkan bila tidak ada wabah pelaksanaanya boleh dilonggarkan.

Penerapan langkah-langkah biosekuriti pada post entry terlihat bahwa dari ketujuh langkah tersebut hanya satu langkah yang masih sama penerapannya yaitu semua kandang pada peternakan yang terlibat memiliki pintu, hanya saja kondisinya barangkali tidak sebaik pada saat proyek sedang berjalan mengingat semua kandang (100\%) bisa dimasuki oleh hewan liar (Tabel 3). Bangunan fisik kedua yang masih terlihat ada adalah pencelup kaki atau footbath di depan pintu kandang yang digunakan untuk membersihkan alas kaki bagi yang akan memasuki kandang. Tetapi sepertinya pencelup itu tidak difungsikan sebagaimana seharusnya mengingat sebagian besar tidak berisi air (25\%) bahkan ada yang sudah menutupnya dengan tanah (Gambar 2), Sehingga tidak bisa diharapkan banyak peternak akan mengisi air dan desinfektan (25\%). Hal ini disebabkan peternak merasa tidak nyaman dan terganggu pada saat membawa pakan memasuki kandang dan lagi mereka mengatakan bahwa perusahaan juga tidak menginstruksikan mereka untuk menggunakan footbath. Memang untuk peternak kemitraan mereka sangat mempercayai dan mudah mengikuti instruksi yang diberikan oleh perusahaan. Padahal peternak menyadari kalau pelaksanaan biosekuriti mereka bagus mortalitas ternak mereka rendah sehingga pendapatan mereka tentunya meningkat, seperti yang diperoleh oleh Sarini et al. (2013) bahwa ada korelasi positif antara status biosekuriti pada peternak ayam broiler dan petelur di tiga propinsi dengan mortalitas dari ayam yang dipelihara. Meskipun tidak ada pertanyaan secara tertulis mortalitas dari peternakan ayam di desa ini rata-rata mereka mengatakan mortalitasnya antara 3-5\% dan nilai tersebut merupakan jumlah yang normal. Semua peternak mengatakan bahwa mereka mengetahui tujuan dari pelaksanaan biosekuriti tetapi karena merasa kondisi aman dan tidak ada yang mengharuskan mereka untuk melaksanakannya adalah hal yang menyebabkan mereka tidak lagi menerapkan biosekuriti secara benar disamping dana yang belum tersedia.

\section{SIMPULAN}

Dari evaluasi ini dapat disimpulkan bahwa pelaksanaan langkah-langkah biosekuriti pada peternakan ayam broiler di Desa Selanbawak, Kecamatan Marga, Kabupaten Tabanan sudah mengalami perubahan dari saat dilaksanakan proyek ACIAR AH 169/2006. Langkah-langkah fisik seperti pagar, pintu pagar, dan footbath meskipun ada tetapi sudah tidak berfungsi sebagaimana mestinya.

\section{UCAPAN TERIMA KASIH}

Penulis mengucapkan terimakasih kepada Rektor dan Ketua Lembaga Penelitian dan Pengabdian kepada Masyarakat Universitas Udayana yang telah memfasilitasi penelitian ini melalui dana PNBP Universitas Udayana Tahun 2016. Penulis juga mengucapkan terimakasih kepada peternak ayam broiler di Desa Selanbawak, Kecamatan Marga, Kabupaten Tabanan yang telah menyediakan waktunya sehingga kegiatan survei dapat berlangsung dengan baik dan lancar.

\section{DAFTAR PUSTAKA}

ABCRC (Australian Biosecurity Cooperative Research Centre for Emerging Infectious Deseases) 2007. The epidmiology, pathogenesis and control of highly pathogenic avian influenza in ducks in Indonesia and Vietnam. ABCRC. Sumber: http://www1.abcrc.org.au/pages / projects.aspx?projectid=117. Diakses: 11 Juli 2007.

ACIAR (Australian Center for International Agricultural Research). 2014. Developing a clean market chain for poultry products in Indonesia.ACIAR technical report No. 82. www. aciar.gov. au, Canberra.

Butcher, G. D; Richard, D.M. 2013. Disease Prevention in Commercial Poultry. University of Florida, IFAS Extention.

FAO. 2008. Biosecurity for Highly Pathogenic Avian Influenza. Animal Production Health. Paper. Rome. Italy.

Jeffrey JS. 2007. Biosecurity for poultry flocks. Poultry Fact Sheet No 26. file://localhost/F:/Folder\%20TinPus/ BIOSECURITY\%2OFOR\%2OPOUL TRY\%2OFLOCKS. htm. Sumber: http://www.vet med.ucdavis.edu/vetext/INF- PO_Biosecurity.html. Diakses:19 Juli 2008.

Patrick, I.W. and T.F. Jubb. 2010. Comparing biosecurity in smallholder broiler and layer farms in Bali and West Java. Proceeding Towards the Adoption of CostEffective Biosecurity on NICPS Farms in Indonesia. Bogor-Indonesia: June 8-9, 2010, p.5-12.

Sugiyono. 2008. Metode Penelitian Bisnis. Penerbit Alfabeta, Bandung.

Sulaiman, A. dan R. Muhammad. 2008. Penerapan Teknologi Biosekuriti Dalam Usaha Pencegahan Penyakit Pada Peternakan Unggas Rakyat: Laporan Penelitian. Fakultas Pertanian Universitas Lambung Mangkurat. 